\title{
Study on the Relationship between Tax Structure and R\&D Investment in China
}

\author{
Yanfeng Jiang \\ Department of Public Economics University of \\ Xiamen, Xiamen 361005, China \\ Jiangyanfeng2011@126.com
}

\begin{abstract}
By the analysis of the MVAR model for the taxes impacting on $R \& D$ investment, this paper mainly analyses the influence of China's tax system and tax structure on R\&D investment the main conclusions of the empirical studies are: (1) the $R \& D$ input is positively correlated to value added tax, consumption tax and personal income tax, but the positive correlation to business tax is not significant; the $R \& D$ input is negatively correlated to corporate income tax and tariff; The impulse responses show the value added tax, consumption tax have a long term continuous positive effect on $R \& D$ input. (2) There exists impulses from the other taxes for the taxes studied, the impulse between value added tax and consumption tax is gradually increasing, business tax and personal income tax have a long-term continuous positive effect on each other. Finally this paper discusses the reform path for the taxes according to the empirical results.
\end{abstract}

Keywords-Index Terms -R\&D investment, Tax reform in China, Multivariate vector auto regression (MVAR), Impulse responses, Tax reform

\section{INTRODUCTION}

According to the definition of American Science Foundation, R\&D (Research and Development) refers to the basic research, applied research and experimental development of government, enterprises and non-profit organizations. The progress of science and technology is an important driving force for economic development. R\&D investment promotes the continuous development of science and technology by seed effect, cause effect, growth effect and self enhancement effect. At the same time, R\&D investment is the important link for enterprises' technological innovation, and is the key factor for economic growth. R\&D investment is an important index to measure the innovation and productivity, and is positively correlated to productivity. A research report of the Economic Report Commission for Clinton in 1995 found the R\&D input explains $50 \%$ of USA economic growth over the past 40 years.

Since the twentieth Century, western countries including USA and European countries, all pay attention to high-tech development especially R\&D input, because they think it is the inherent power of the sustained rapid economic growth in Japan and South Korea, so recently all the countries pay special attention to rendering more tax preferences for innovators, in order to promote their own R\&D investment.
Tax policy, as one of the policies that encourage enterprises' technology innovation and increase $\mathrm{R} \& \mathrm{D}$ investment, compared with the other fiscal policies, is with market orientation, highly predictable for enterprises, with lower operating costs, highly transparent and available etc., therefore, more and more countries begin to use tax measures to encourage innovation.

We examine the relationship between tax revenue and R\&D input. On one hand, if tax increases, then the government will have more funds for R\&D investment. But on the other hand, tax would also reduce the enthusiasm of $R \& D$ investment for enterprises. So the relationship between tax revenue and $\mathrm{R} \& \mathrm{D}$ input is not clear. This paper selects the main tax revenue in China as the research subjects, and focus on the following questions: (1) Is there a significant and positive impact for tax revenue on $R \& D$ input? investigate the endogeneity of the relationship between tax income and R\&D input, empirically test whether there exists two-way relationships between taxes and R\&D input. Through the analysis of China's tax revenue and the current situation, we put forward the reform proposals from the perspective of improving R\&D input.

\section{LITERATURE REVIEW}

The related literatures mainly study the relationship between tax policy and R\&D input. There are two kinds of views, that theories support tax preference for $R \& D$ input and those suspect that. Those supporters belief tax relief can stimulate R\&D investment for enterprises, but the phalanxes deem tax relief can not have a material impact on $R \& D$.

The representative research that support tax preference for R\&D input include: Bernstein (1986) [1] using the framework of production structure analysed tax credit and special tax allowance for research and development investment for 27 Canadian companies in 1975-1980, with the typical and time series data, the study found, for every $\$ 1$ tax expenditure, the new capital of enterprise development will be more than $\$ 1$. Guellec and Van Pottelsberghe (2003) [2] researched the effectiveness of the preferential tax policy using the data of 17 OECD countries. The results show that, R\&D spending for the tax price elasticity is negative, that is to say, tax credit would bring the reduced $R \& D$ cost, and this could promote the growth of R\&D spending. The absolute value for long term 
R\&D price elasticity is greater than the short term price elasticity, this suggest that short term incentive effect of preferential tax policies is relatively weak, and long term incentive effect is good. The policy implication is that stability of tax policy can influence policy performance. Bloom et al. (2002)[3] demonstrated that tax credits have a long term effect on the R\&D expenditure, if the cost of R\&D funds drop per $1 \%$, then R\&D spending would increase by about $1.5 \%-1.8 \%$.

The representative research that oppose tax preference for R\&D input include: Estache and Gaspar (1995) [4] using the marginal effective tax rate model (King \& Fullerion model) assessed Brazil's tax preferences, and found the reduction effect for effective marginal tax rate is not obvious, a wide range of tax incentives will make the tax system distorted. Boadway (1995)[5] assessed the incentive effect on the hightech enterprises in Malaysia for 5 years of tax exemption, concluded that the exemption period was with little significance for weak and naive investors. At the same time, Boadway (1995)[6] studied the investment incentive effect of indirect tax in Malaysia, found the indirect tax would cause serious distortions for investment, and the distortions would be different to the different sectors, especially provided subsidies to import trades, but punished the export sectors. For example, the distortion for trade tax in investment was about $2 / 3$. He recommended a appropriate tariff reduction and a wide base of value added tax. Rajagopal and Shah (1995)[7]using production structure analysis, studied tax incentive effect on R\&D in Turkey, Pakistan and Mexico, and found the incentive effect of tax policy only happened in partial chemical industries.

For the existing literature on the relationship between tax policy and the R\&D input, scholars focus mainly on whether the tax policy is effective and the effectiveness degree etc., and most of the research are empirical analysis, by setting up a lot of evaluation models, provides some good ideas and methods for studying the incentive effect of $R \& D$ tax policies.

This paper try to make improvements in the following aspects: (1) The existing studies focus on specific business, industry and a particular tax, this paper selects six main taxes to study the long-term relations between various taxes and R\&D input, attempts to prove the function for the tax to $R \& D$ input and demonstrate the long-term trend. And also by using the impulse response, try to analyses the influence between the taxes, and demonstrate the short term fluctuations for the tax and R\&D input. (2) Different to the previous literature, this paper investigates the endogeneity of the relationship between tax income and R\&D input by the MVAR method, and through the analysis of the linkage between the taxes, indicates that policy makers should pay attention on increasing the R\&D input and the coordination between taxes. We should develop targeted measures to promote R\&D input and optimize the tax structure.

\section{EMPIRICAL STUDY ON THE RELATIONSHIP BETWEEN THE R\&D INPUT AND THE TAX REVENUE}

This paper attempts to demonstrate whether there exists the two-way relationship between tax revenue and $R \& D$ input through the cointegration analysis, and further investigate the taxes that influence R\&D input by the VAR modeling analysis.
Further, study on the different effects for taxes on R\&D input and the endogeneity problem.

\section{A. The variables and data}

We select the main six taxes(domestic value-added tax $Z Z$, domestic consumption tax $X F$, business tax $Y Y$, tariff $G S$, business income taxes $G Y$, personal income tax $G R$ ) in the tax structure in 1990-2010 in China, and the natural logarithm of statistical data for the main six taxes are regression variables for the logarithm of R\&D input. The data includes: "China's statistical yearbook 2011", the Ministry of finance website, the Ministry of science and technology website, and the National Bureau of Statistics website, etc.

\section{B. Stationary test for variables}

From the stationary test results in TABLE 1, the natural logarithm of the statistical data (R\&D input RD, domestic value added tax $Z Z$, domestic consumption tax $X F$, business tax $Y Y$, tariff $G S$, enterprise income tax $G Y$, personal income $\operatorname{tax} G R$ ) are not stationary, but the first differences of the variables are stationary (one order integration), so we can establish the econometric model and test the data.

TABLE 1 Stationary Test (ADF) of Variables

\begin{tabular}{|c|c|c|c|c|}
\hline Variables & test type & $\mathrm{ADF}$ & $5 \%$ & Con. \\
\hline $\operatorname{lnrd}$ & (C $\left.\begin{array}{lll}\text { L } & 1\end{array}\right)$ & 2.5874 & -3.2251 & Non \\
\hline $\mathrm{D}(\operatorname{lnrd})$ & $\left(\begin{array}{lll}C & 1 & 0\end{array}\right)$ & -3.7745 & -3.2017 & Yes \\
\hline Lnzz & (C 111$)$ & -1.3470 & -3.1753 & Non \\
\hline D(Lnzz) & $\left(\begin{array}{lll}C & 0 & 0\end{array}\right)$ & -2.7570 & -2.1476 & Yes \\
\hline $\ln x f$ & $\left(\begin{array}{lll}C & 1 & 1\end{array}\right)$ & 2.1666 & -3.2126 & Non \\
\hline$D(\ln x f)$ & $\left(\begin{array}{lll}\mathrm{C} & 0 & 1\end{array}\right)$ & -5.4880 & -3.2598 & Yes \\
\hline Lnyy & (C 111$)$ & 1.7647 & -3.1753 & Non \\
\hline D(Lnyy) & $\left(\begin{array}{lll}C & 1 & 0\end{array}\right)$ & -3.3837 & -3.3209 & Yes \\
\hline $\operatorname{lngr}$ & $\left(\begin{array}{lll}C & 0 & 0\end{array}\right)$ & -3.852 & -3.1753 & Yes \\
\hline lngs & (C 1 ll) & 1.0971 & -3.2598 & Non \\
\hline $\mathrm{D}$ (lngs) & $\left(\begin{array}{lll}\mathrm{C} & 0 & 0\end{array}\right)$ & -5.5415 & -3.3209 & Yes \\
\hline $\operatorname{lnqy}$ & $\left(\begin{array}{lll}C & 1 & 1\end{array}\right)$ & -1.0523 & -3.3426 & Non \\
\hline D(lnqy) & $\left(\begin{array}{lll}C & 1 & 0\end{array}\right)$ & -3.8614 & -3.6732 & Yes \\
\hline
\end{tabular}

C. The co-integration test and estimation for the economic model

When the variables are with the one order integration and the data is stationary, we can study on the long-term equilibrium relationship between the selected variables. This paper will investigate the relationship between R\&D investment and tax income by co-integration test in TABLE 2 and TABLE 3.

TABLE 2 and TABLE 3 show there exists at least two cointegrations, and the optimal lag order is determined by the AIC criterion, so we can construct the model to investigate the long-term relationship between the R\&D input and the tax revenue in TABLE 4. 
TABLE 2 Johansen Unrestricted Co-integration Trace Test

\begin{tabular}{ccccc}
$\begin{array}{c}\text { Hypothesized } \\
\text { No. of CE(s) }\end{array}$ & Eigenvalue & $\begin{array}{c}\text { Trace } \\
\text { Statistic }\end{array}$ & $\begin{array}{c}0.05 \\
\text { Critical Value }\end{array}$ & Prob.** \\
\hline \hline & & & & \\
None* & 0.880315 & 69.77152 & 27.88204 & 0.0000 \\
At most 1* & 0.697352 & 25.00167 & 14.33159 & 0.0026 \\
At most 2* & 0.700667 & 12.00153 & 2.77526 & 0.0007 \\
\hline \hline
\end{tabular}

Trace test indicates 3 co-integrating equation(s) at the 0.05 level.

TABLE 3 Johansen Unrestricted Co-integration Maximum Eigenvalue Test

\begin{tabular}{|c|c|c|c|c|}
\hline $\begin{array}{l}\text { Hypothesized } \\
\text { No. of CE(s) }\end{array}$ & Eigenvalue & $\begin{array}{c}\text { Max-Eigen } \\
\text { Statistic }\end{array}$ & $\begin{array}{c}0.05 \\
\text { Critical } \\
\text { Value }\end{array}$ & Prob** \\
\hline None* & 0.885413 & 47.33125 & 20.33175 & 0.0000 \\
\hline At most 1 & 0.799145 & 13.00152 & 14.26460 & 0.0986 \\
\hline At most $2 *$ & 0.677852 & 12.10375 & 3.796709 & 0.0046 \\
\hline
\end{tabular}

(3) Personal income tax has a positive impact on the R\&D input, this seems not fit to the reality. in our intuition, when the personal income tax increase, the enthusiasm of innovation and technology for scientific and technical personnel will be inhibited, and the R\&D input will be reduced. Why personal income tax has a positive impact on the $R \& D$ input in China, the possible reason is that, the supply of science and technology personnel excess the demand recently in China, so the income effect is greater than the substitution effect for the income from innovation. The tax will encourage researchers to work harder.

\section{THE MVAR ANALYSIS FOR R\&D INVESTMENT AND TAX STRUCTURE}

The co-integration regression results of the $R \& D$ input and the tax revenue show $R \& D$ investment is positively related to value-added tax, consumption tax and personal income tax, and negatively related to enterprise income tax and tariff. Based on this, this part would classify the selected taxes, and set up the multivariate vector auto regression model (MVAR), deeply investigate the endogeneity. We determine the impulse order according to the effect size of variables. The results are in TABLE 5 and TABLE 6.

TABLE 5 The MVAR Analysis for R\&D Investment and Tax Structure (Co-

TABLE 4 The Co-Integration Regression Results for R\&D Inputs and the Tax Revenue.

\begin{tabular}{l|l|l|l|l|l|l}
\hline & $\operatorname{lnZZ}$ & $\operatorname{lnXF}$ & $\operatorname{lnGR}$ & $\ln Y Y$ & $\operatorname{lnGS}$ & $\operatorname{lnGY}$ \\
\hline $\ln R D$ & $0.6770^{*}$ & $0.2959^{*}$ & $0.3105^{*}$ & 0.0778 & $0.0459 * *$ & $0.0911^{* *}$ \\
& $*$ & $*$ & $*$ & $(0.2040$ & $*$ & $*$ \\
& $(2.2609)$ & $(2.6290)$ & $(2.7012)$ & ) & $(-1.8417)$ & $(-1.8136)$ \\
\hline
\end{tabular}

Notes: $* * *, * * *$, ,represents $1 \%, 5 \%, 10 \%$ significance level respectively.

The co-integration regression results show:

(1) The residual series of co-integration equations are stationary, and the overall explanation of the model is good, show that there exist co-integration for R\&D input and the tax revenue, demonstrating that the $R \& D$ input would change with the tax revenue.

(2) The elasticity of value-added tax on R\&D is 0.677 ,shows that R\&D input swill increase $0.677 \%$ if valueadded tax increase 1\%; the elasticity of consumption tax on R\&D is 0.2959 , shows that R\&D input will increase $0.2959 \%$ if consumption tax increase $1 \%$; the elasticity of personal income tax on $\mathrm{R} \& \mathrm{D}$ is 0.3105 , shows that $\mathrm{R} \& \mathrm{D}$ input will increase $0.3105 \%$ if personal income tax increase $1 \%$; the elasticity of business tax on R\&D is 0.0778 , shows that R\&D input will increase $0.0778 \%$ if business tax increase $1 \%$, but the positive effect for business tax on $R \& D$ input is not significant; R\&D input reversely change with tariff and enterprise income tax, and the negative relationship is significant, Granger causality test results show value added tax, consumption tax and personal income tax are all the Grainger reasons of $R \& D$ input, and that there exist short-term modified relations for the variables by the error correction model in cointegration equation. integration coefficient is positive)

\begin{tabular}{|c|c|c|c|c|c|}
\multicolumn{7}{c|}{ integration coefficient is positive) } \\
\hline \multirow{2}{*}{$\mathrm{C}$} & $\operatorname{lnZZ}$ & $\operatorname{lnGR}$ & $\operatorname{lnXF}$ & $\operatorname{lnYY}$ & $\operatorname{lnGR}$ \\
& -0.8631 & 1.4001 & 5.1195 & -1.5913 & -3.0710 \\
& $(-0.3155)$ & $(0.4863)$ & $(0.6691)$ & $(-0.8396)$ & $(-2.1823)$ \\
\hline $\operatorname{lnZZ} \mathrm{t}-1$ & 1.7306 & 0.1618 & -2.1124 & 1.0221 & 0.9272 \\
& $(1.6492)$ & $(0.1464)$ & $(-0.7196)$ & $(1.4056)$ & $(1.7174)$ \\
\hline $\operatorname{lnGR} \mathrm{t}-1$ & -0.0218 & 0.2978 & -0.1900 & -0.0904 & 0.0549 \\
& $(-0.0772)$ & $(1.001)$ & $(-0.2404)$ & $(-0.4617)$ & $(0.3777)$ \\
\hline $\operatorname{lnXF_{t}-1}$ & 0.2539 & -0.0500 & -0.0523 & 0.2993 & 0.3079 \\
& $(0.6968)$ & $(-0.1301)$ & $(-0.0513)$ & $(1.1851)$ & $(1.6421)$ \\
\hline $\ln \mathrm{YY}_{\mathrm{t}-1}$ & -0.9702 & -0.4905 & 1.2375 & -0.1871 & -0.0437 \\
& $(-0.8499)$ & $(-0.5010)$ & $(0.4758)$ & $(-0.2905)$ & $(-0.0914)$ \\
\hline $\operatorname{lnRD} \mathrm{D}_{\mathrm{t}-1}$ & -0.1109 & 0.9130 & 1.7430 & 0.0905 & 0.0186 \\
& $(-0.1240)$ & $(0.9695)$ & $(0.6967)$ & $(0.1460)$ & $(0.0404)$ \\
\hline
\end{tabular}

TABLE 6 The MVAR Analysis For R\&D Investment and Tax Structure (Cointegration coefficient is negative)

\begin{tabular}{|c|c|c|c|}
\hline & $\operatorname{lnGS}$ & $\operatorname{lnQY}$ & $\operatorname{lnRD}$ \\
\hline $\mathrm{C}$ & $\begin{array}{c}1.4135 \\
(4.5887) \\
\end{array}$ & $\begin{array}{c}-2.4667 \\
(-1.1520) \\
\end{array}$ & $\begin{array}{c}0.1812 \\
(0.4209) \\
\end{array}$ \\
\hline $\operatorname{lnGS} S_{t-1}$ & $\begin{array}{c}-0.3728 \\
(-1.3850)\end{array}$ & $\begin{array}{c}0.9086 \\
(1.5166)\end{array}$ & $\begin{array}{c}0.0173 \\
(0.1437)\end{array}$ \\
\hline $\ln Q Y_{t-1}$ & $\begin{array}{c}-0.2504 \\
(-2.0760)\end{array}$ & $\begin{array}{c}0.2865 \\
(1.0668)\end{array}$ & $\begin{array}{c}0.0015 \\
(0.0274) \\
\end{array}$ \\
\hline $\ln R D_{t-1}$ & $\begin{array}{c}0.9578 \\
(4.9773)\end{array}$ & $\begin{array}{c}0.3075 \\
(0.7179)\end{array}$ & $\begin{array}{c}0.9578 \\
(4.9773)\end{array}$ \\
\hline
\end{tabular}

The impulse analysis for the variables with positive Cointegration coefficients: 


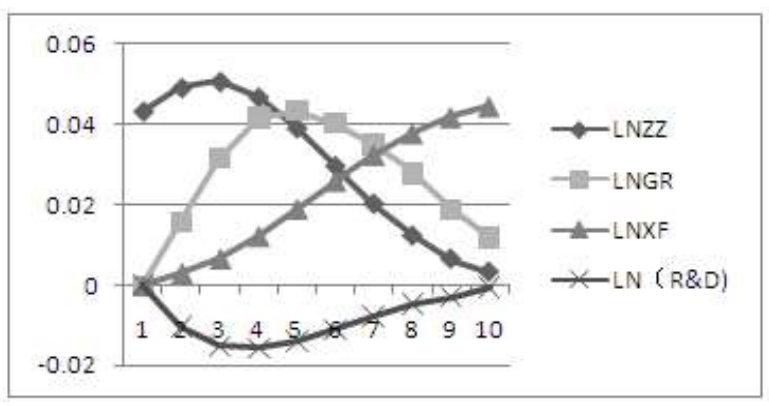

Figure 1. LNZZ impulse responses

The Fig. 1 shows the impulse responses of value added tax for value added tax, personal income tax, consumption tax and R\&D investment. The impulse response is negative for $R \& D$ investment, this negative influence gradually increased to 0.015558 in the former 4 periods, and the negative influence begin to wane in 5 th period, then gradually decline to 0 . The possible reason is, the innovation gains for $R \& D$ investment exists 4 period lag, in the fifth period the gains begin significant for R\&D activities, the improved economic benefits could increase the value added tax income. At the same time, the impulse response of value added tax is long lasting positive for the consumption tax. The impulse response of value added tax for personal income tax first increased and then decreased, and the peak is in the 5th period; the impulse response of value added tax for personal income tax is gradually weaker negative, in the sixth period the response is positive, then is gradually weaker positive.

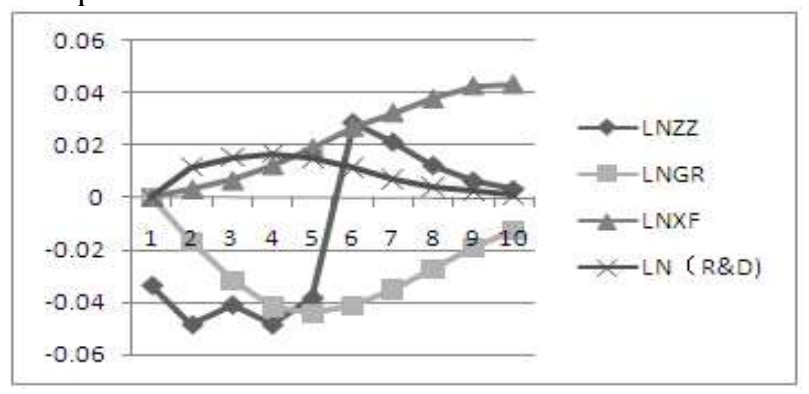

Figure 2. LNGR impulse responses

The Fig.2 shows the impulse responses of personal income tax for value added tax, personal income tax, consumption tax and $R \& D$ input. The impulse response is positive for $R \& D$ investment, The maximum is 0.016567 in the 4 th period, and then begin to decline and maintain a gradually weaker positive response. The possible reason is, $R \& D$ investment could immediately increases the income for the R\&D personnel, with economic gains begin significant, personal income tax will increase, and reach the maximum in the 4th period, then begin to wane. At the same time, the impulse response of personal income tax for value added tax is gradually weaker negative, in the 6th period is positive, and then is gradually weaker positive. The impulse response of personal income tax for consumption tax is significant positive.

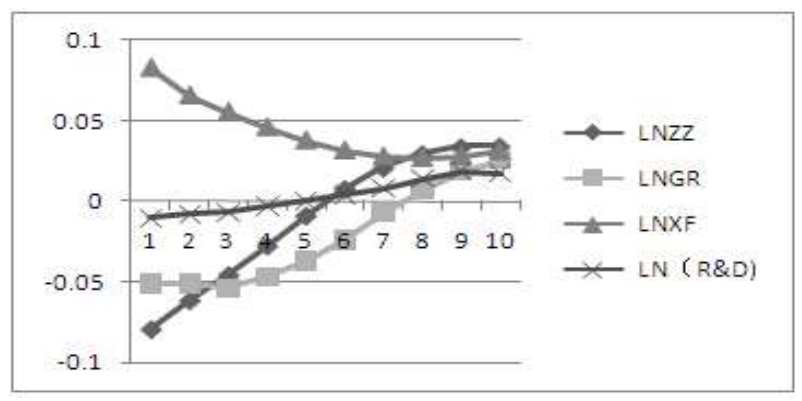

Figure 3. LNXF impulse responses

The Fig. 3 shows the impulse responses of consumption tax for value added tax, personal income tax, consumption tax and R\&D input. The initial impulse response is gradually weaker negative for R\&D investment, in the 5th period is beginning to turn positive, and reach to the maximum 0.018522 in the 9th period. The possible reason is, R\&D investment will reduce the funds for consumption, and then will reduce the consumption tax revenue. But with the economic benefit for R\&D investment become significant, the wealth of society will increase in general, and correspondingly increase the funds for consumption, finally the consumption tax revenue will increase. At the same time, the impulse response of consumption tax for itself is the most important. the impulse responses of consumption tax for value added tax and personal income tax, are both firstly positive and then negative

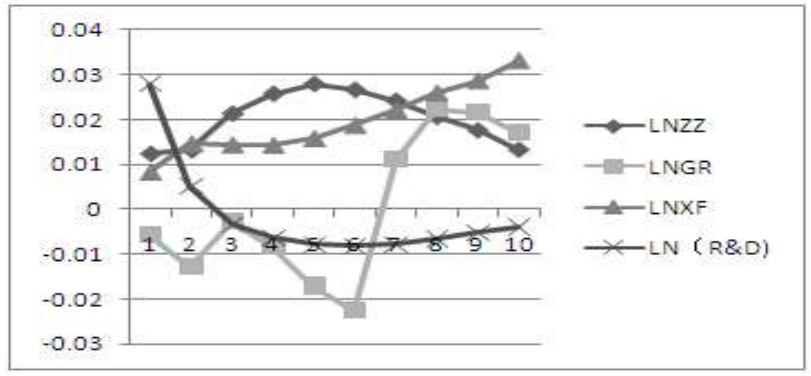

Figure 4. $\mathrm{LN}(\mathrm{R} \& \mathrm{D})$ impulse response

The Fig. 4 shows the impulse responses of R\&D input for value added tax, personal income tax, consumption tax and R\&D input. As shown in the co-integration equation, the impulse response of $R \& D$ input for value added tax is positive, and reaches to the maximum value 0.027855 in the 5 th period, then gradually decline and become steady. The impulse response of $R \& D$ input for personal income tax is fluctuant and negative in the former 6 periods, in the 7th period, the impulse response begins positive, and then become gradually intense. The impulse response of $R \& D$ input for consumption tax is increasing positive. the impulse response of R\&D input for itself is gradually weaker positive in the former 2 periods, and become negative in the 3 th period, reach to the minimum 0.008156 in the 6th period, and then is gradually weaker negative.

According to the results of the analysis of co-integration equation and M-VAR model, we can draw the following conclusions: 
(1) There are significant positive correlations between R\&D investment and value added tax, personal income tax, consumption tax. The impulse responses show, the positive effect of R\&D input on consumption tax continues to rise from the first period. And the long-term trend shows, there exists significant positive effect of consumption tax on R\&D input. The impulse is non-significant negative from personal income tax on R\&D input in the former 4 periods, and then gradually become weak positive. For the impulse from the value added tax, there exists a weak positive response of R\&D input and the response first increase then decrease. For the impulse from business tax, there exists a steady weak positive response of R\&D input.

(2) There are negative correlations between $R \& D$ input and tariff, enterprise income tax. The impulse response of $\mathrm{R} \& \mathrm{D}$ input to enterprise income tax is long term steady negative. So for the fluctuation of enterprise income tax, the R\&D input would fluctuate in the opposite direction. At the same time the negative effect on R\&D input from tariff should not be neglected.

(3) The tax would also be affected from other taxes. The impulse response of value added tax to consumption tax is long term steady positive, the impulse response of value added tax to personal income tax first increase then decrease, and reach the peak in the 5th period; the impulse response of value added tax to personal income tax is steady and significant; the impulse response of consumption tax to itself is the most significant, to the impulse from value added tax and personal income tax, the impulse response of consumption tax are both first positive then negative.

\section{CONClusions AND SUGGESTIONS}

By the analysis of the MVAR model for the taxes impacting on R\&D investment, this paper mainly analyses the influence of China's tax system and tax structure on R\&D investment.

the main conclusions of the empirical study are:(1), the R\&D input is positively correlate to value added tax, consumption tax and personal income tax, but the positive correlation to business tax is not significant; the R\&D input is negatively correlate to corporate income tax and tariff. The impulse responses show the value added tax, consumption tax have long term continuous positive effect on R\&D input. (2), there exist impulses from the other taxes for the taxes studied, the impulse between value added tax and consumption tax is gradually increasing, business tax and personal income tax have long-term continuous positive effect on each other.

According to the empirical results, then we try to discuss the reform path for the taxes to encourage R\&D input:

(1) Continue to promote the reform of "business tax change into value added tax", according to the industry and regional characteristics, further explore the feasible way of the reform of "the business tax change into value added tax", and improve the technology, service, tax rate, regulatory and other aspects, from the not significant positive effect of business tax switch to the significant positive effect of value added tax on R\&D input.

(2) Expanse the scope and increase the amount of consumption tax, and further refine the tax items of the consumption tax, take advantage of the long-term positive effect of consumption tax on R\&D input. At the same time, optimize the consumption tax rate structure, explore the optimal function between the consumption tax and the R\&D input, and formulate policies and management strategies for the consumption tax, in order to encourage $R \& D$ investment and innovation for enterprises, and achieve multiple goals of environmental protection, tax equity and the adjustment of economic structure.

(3) Formulate the long-term development strategy of the tariff policy, and reduce its long-term negative impact on R\&D input. The government should not significantly increase the tariff level in the current international and domestic situation, and slightly reduce tariff tax if the condition compatible.

(4) The negative effect of enterprise income tax on $R \& D$ input is the most obvious, currently we should stabilize the enterprise income tax policy, at the same time, continue to explore the policy space that can reduce the corporate income tax, for example, further improve preferential tax for the hightech enterprises etc.

(5) Personal income tax has a positive impact on the R\&D investment currently, but along with the international flow of talents and competition, this negative effect in the long term would not last. We should perfect the collection and service mode of individual income tax, explore the tax credit policies that can encourage important innovation activities of science and technology for personal income tax.

\section{REFERENCES}

[1] Bernstein Jeffrey I, "The effect of direct and indirect tax incentives on Canadian industrial R\&D expenditures", Canadian Public Policy, 12(3), 1986, pp. 438-446.

[2] Guellec, D. \&Van Pottelsberghe, "The impact of public R\&D Expenditure on business R\&D", Economics of Innovation and New Technology, 12, 2003, pp. 225-243.

[3] Bloom, N., N. Griffith and J. Van Reenen, "Do R\&D Tax Credits Work? Evidence from a Panel of Countries 1979-1997", Journal of Public Economics, 85(1) , 2002, pp.1-31.

[4] Estache, A. and V. GasPar, why Tax Incentives Do Not Promote Investment in Brazil, in a .shahed riscal incentives for investment and innovation, Oxford University press, 1995, pp.309-340.

[5] Boadway, R.W., D. Chua and F. Flatters, Investment Incentives and the Corporate Tax System in Malaysia, in A. Shah, ed., Fiscal Incentives for Investment and Innovation, Oxford University press, 1995, PP. 341-374.

[6] Boadway, R.W., D. Chua and F. Flatters, Indirect Tax and Investment Incentives in Malaysia, in A. Shah, ed., Fiscal Incentives for Investment and Innovation, Oxford University press, 1995, PP.375-398.

[7] Rajagopal Shah, Fiscal incentives for investment and innovation, Edited by Anwar shah, the world bank, 1995. 